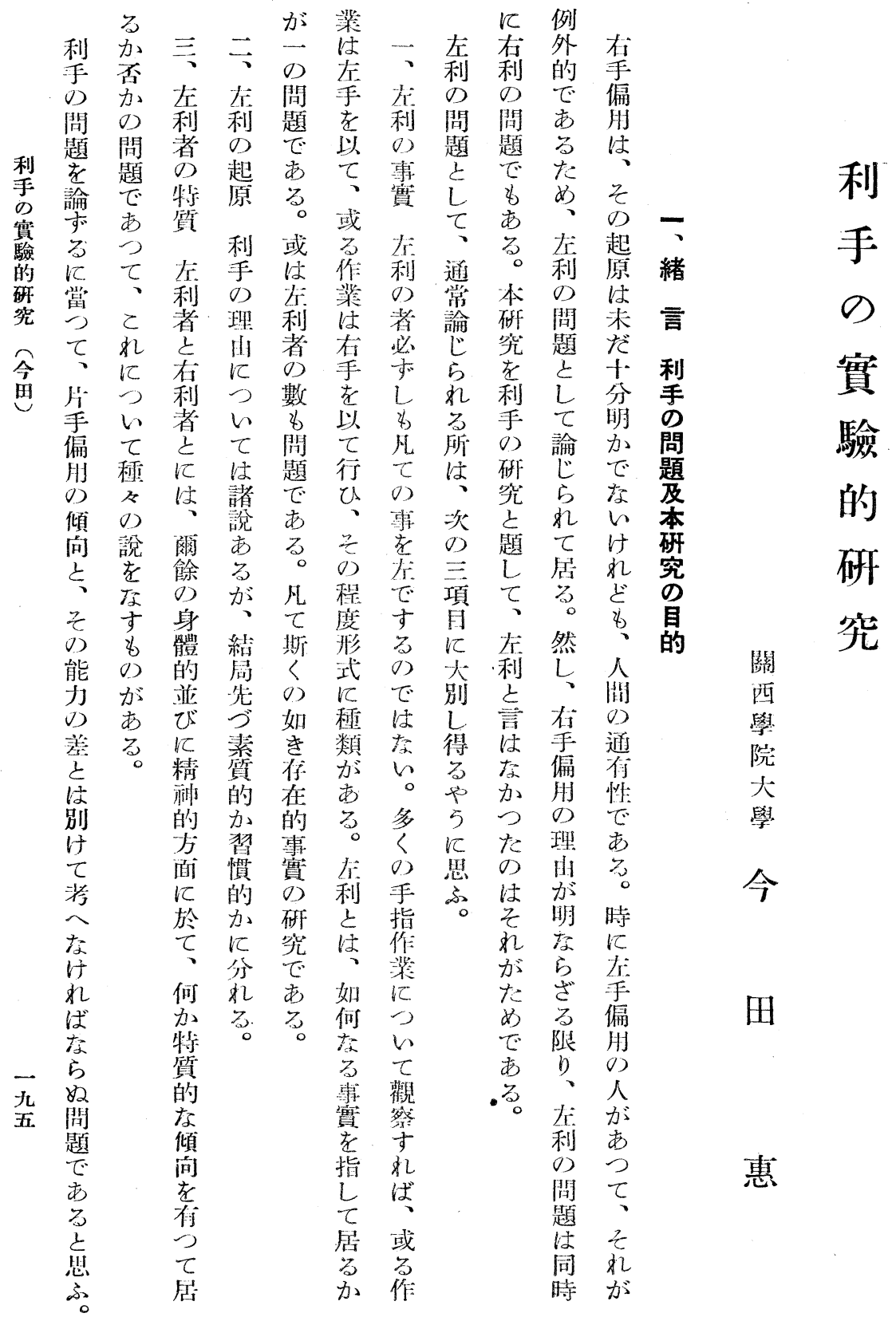




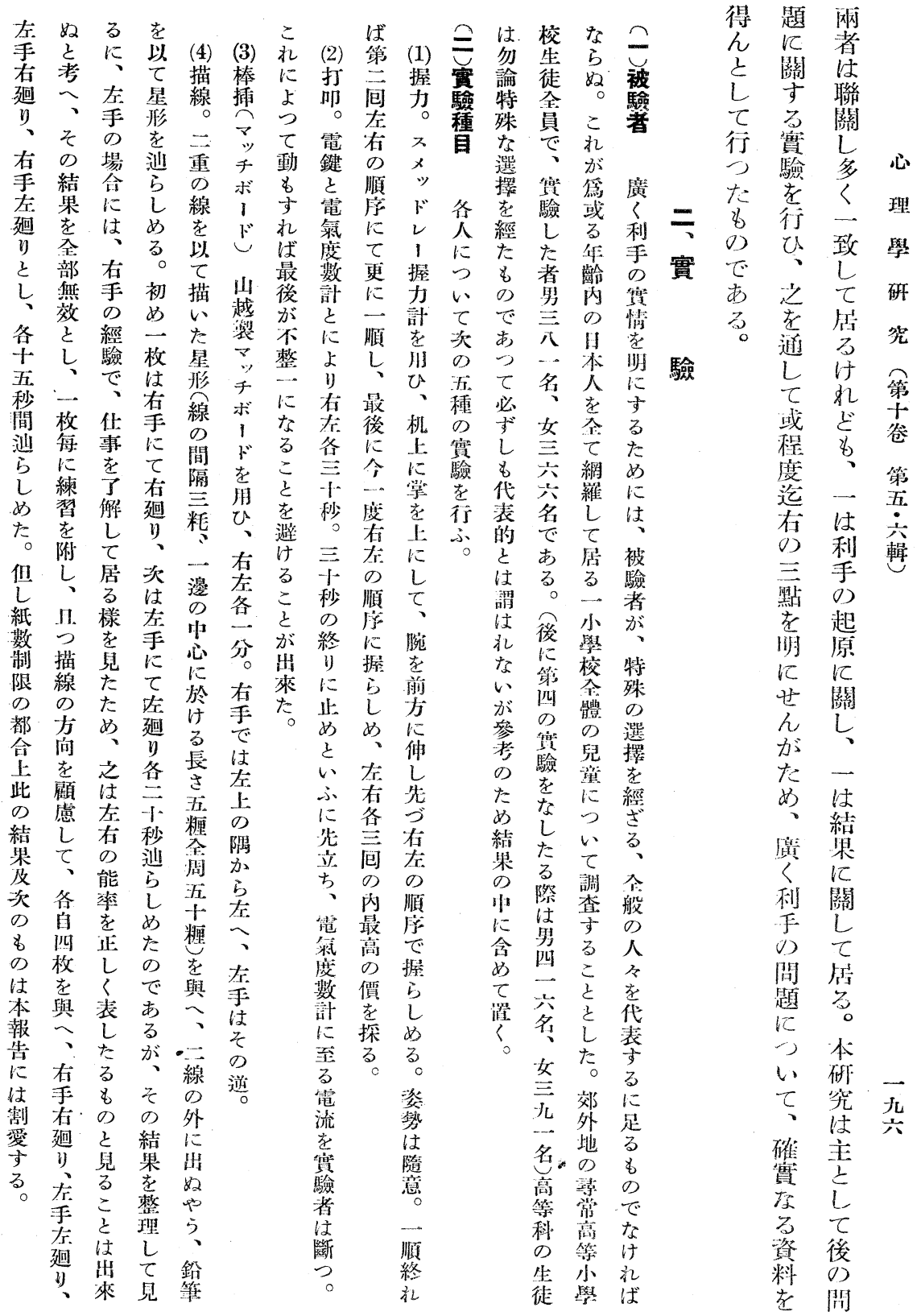




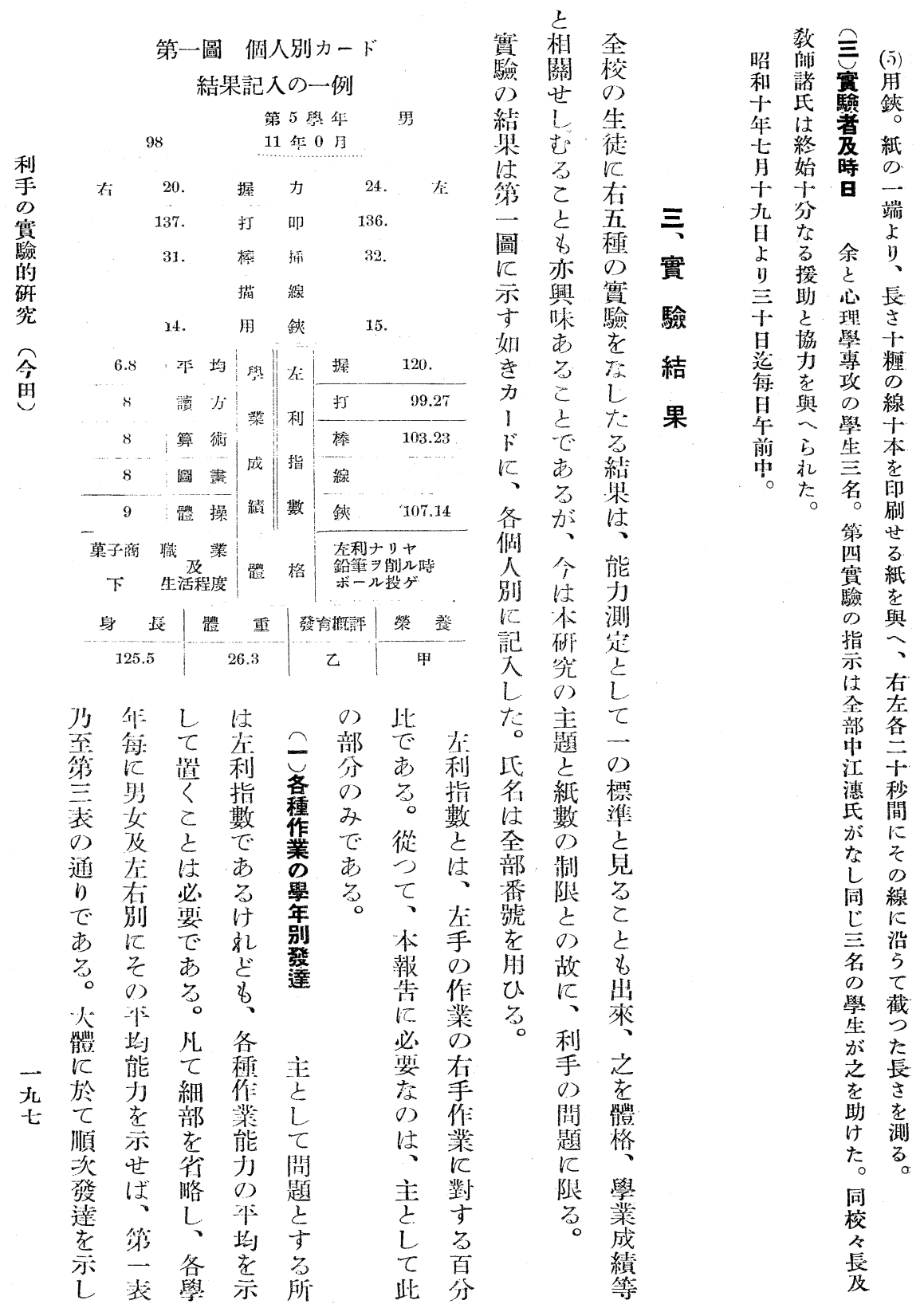


第一表 各學年男女別握力斗均(左右各三回最高)

單位 $\mathrm{Kg}$.

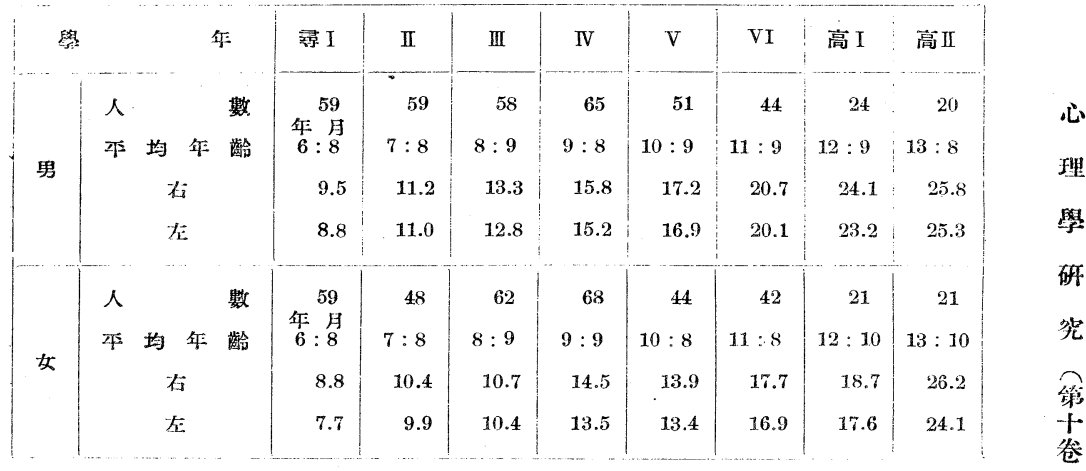

第二表 各學年男女别打叮數本均(左右各三十秒間)

\begin{tabular}{|c|c|c|c|c|c|c|c|c|c|c|c|}
\hline \multicolumn{2}{|c|}{ 學 } & \multicolumn{2}{|c|}{ 年 } & 读 I & II & III & IV & V & VI & 高 I & 高Il \\
\hline \multirow{4}{*}{ 男 } & 人 & & 數 & 年: $\begin{array}{r}59 \\
\text { 月 }\end{array}$ & 59 & 58 & 65 & 52 & 44 & 24 & 20 \\
\hline & 가 & 均 年 & 齗合 & $6: 8$ & $7: 8$ & $8: 9$ & $9: 8$ & $10: 9$ & $11: 9$ & $12: 9$ & $13: 8$ \\
\hline & & 在 & & 105.9 & 118.6 & 125.1 & 136.5 & 143.8 & 161.4 & 156.9 & 174.6 \\
\hline & & 左 & & 90.4 & 101.1 & 106.5 & 115.5 & 124.9 & 142.5 & 140.3 & 151.8 \\
\hline \multirow{4}{*}{ 女 } & 人 & & 數 & $\begin{array}{c}56 \\
\text { 仵 } \quad \text { 月 }\end{array}$ & 48 & 62 & 68 & 44 & 42 & 22 & 21 \\
\hline & & 均 年 & 蕃会 & $6: 8$ & $7: 8$ & $8: 9$ & $9: 9$ & $10: 8$ & $11: 8$ & $12: 9$ & $13: 10$ \\
\hline & & 在 & & 107.2 & 115.3 & 134.9 & 137.5 & 142.5 & 153.8 & 156.1 & 169.0 \\
\hline & & 左 & & 90.3 & 98.7 & 117.0 & 121.0 & 127.6 & 135.4 & 139.4 & 145.1 \\
\hline
\end{tabular}

心

理

學

研

究

第

替

第

五

兗

第三表 各學年男女別棒插平均(左右各一分間ニサシタル數)

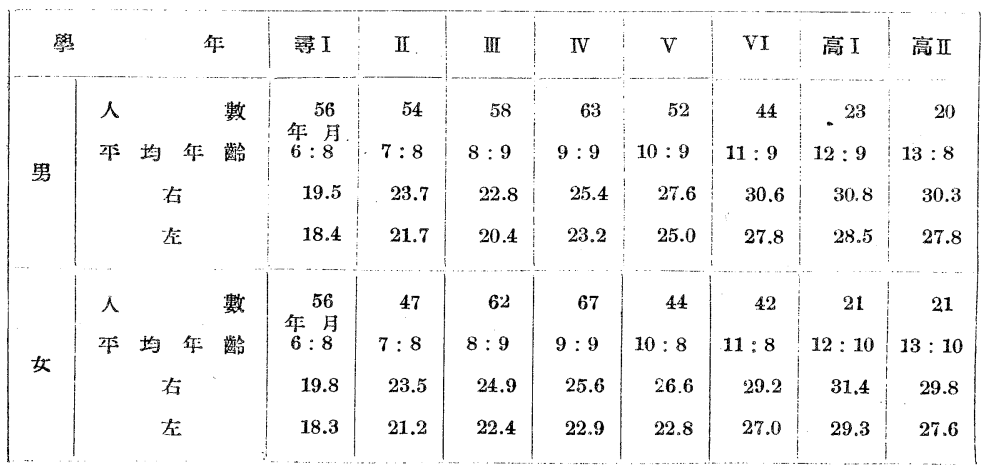


第四表平均值 $=$ ル左右ノ比 $\left(\frac{\text { 右 }}{\text { 右 }} \times 100\right)$

\begin{tabular}{|c|c|c|c|c|c|c|c|c|c|c|}
\hline 學 & 年 & 糟 I & II & III & IV & $\mathrm{V}$ & VI & 高 I & II & 平 均 \\
\hline 握 力 & $\begin{array}{l}\text { 男 } \\
\text { 女 }\end{array}$ & $\begin{array}{l}92.31 \\
87.14\end{array}$ & $\begin{array}{l}98.21 \\
97.19\end{array}$ & $\begin{array}{r}96.23 \\
97.19\end{array}$ & $\begin{array}{l}96.20 \\
92.83\end{array}$ & $\begin{array}{l}98.26 \\
96.12\end{array}$ & $\begin{array}{l}97.10 \\
95.25\end{array}$ & $\begin{array}{l}96.30 \\
94.02\end{array}$ & $\begin{array}{l}98.06 \\
92.06\end{array}$ & $\begin{array}{l}96.58 \\
93.71\end{array}$ \\
\hline 打 听 & $\begin{array}{l}\text { 男 } \\
\text { 女 }\end{array}$ & $\begin{array}{l}85.46 \\
84.31\end{array}$ & $\begin{array}{l}85.24 \\
85.60\end{array}$ & $\begin{array}{l}85.14 \\
86.73\end{array}$ & $\begin{array}{l}84.62 \\
88.00\end{array}$ & $\begin{array}{l}86.86 \\
89.54\end{array}$ & $\begin{array}{l}88.29 \\
88.04\end{array}$ & $\begin{array}{l}89.43 \\
89.25\end{array}$ & & $\begin{array}{l}86.50 \\
87.17\end{array}$ \\
\hline 棒 & $\begin{array}{l}\text { 男 } \\
\text { 女 }\end{array}$ & & & & & $\begin{array}{l}90.43 \\
86.03\end{array}$ & $\begin{array}{l}90.83 \\
92.50\end{array}$ & $\begin{array}{l}92.53 \\
93.47\end{array}$ & $\begin{array}{l}91.58 \\
92.65\end{array}$ & $\begin{array}{l}91.54 \\
90.87\end{array}$ \\
\hline
\end{tabular}

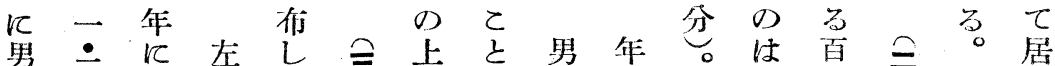

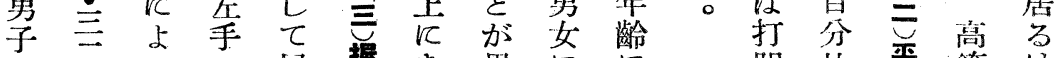

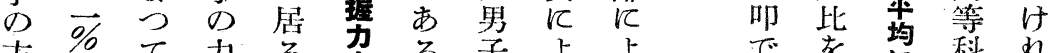

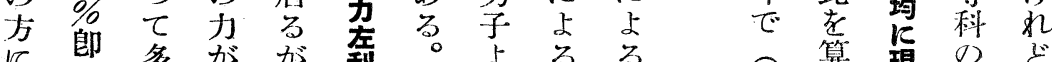

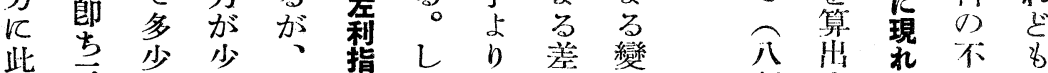

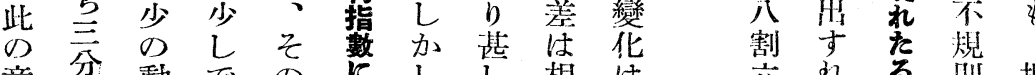

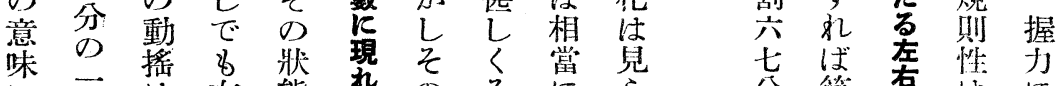

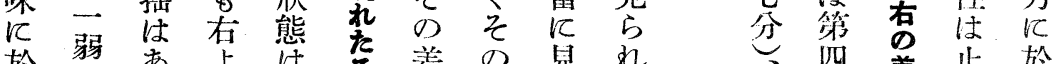

於弱あ占は等差の見狄 四差止於

け名 る

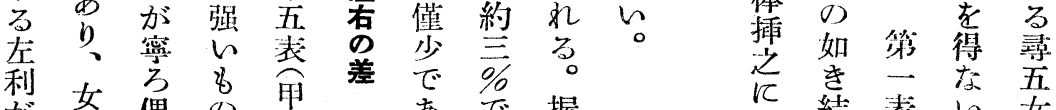

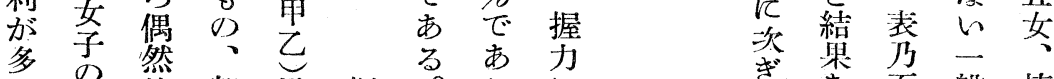

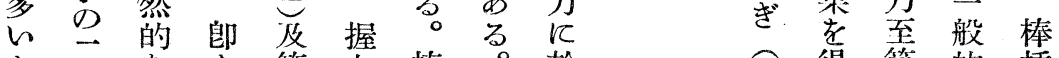

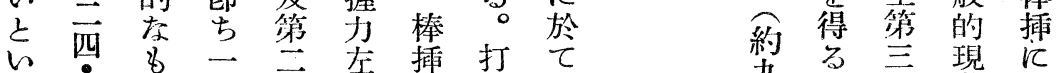

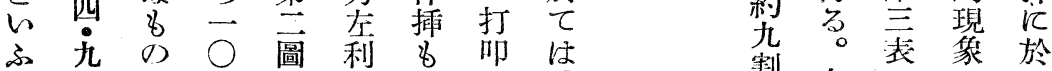

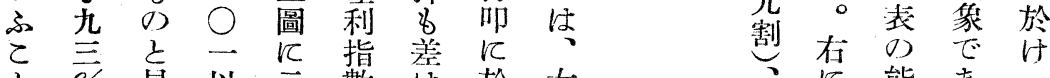

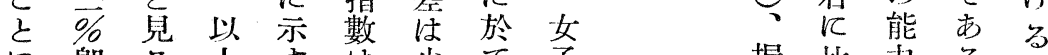

瑯 る

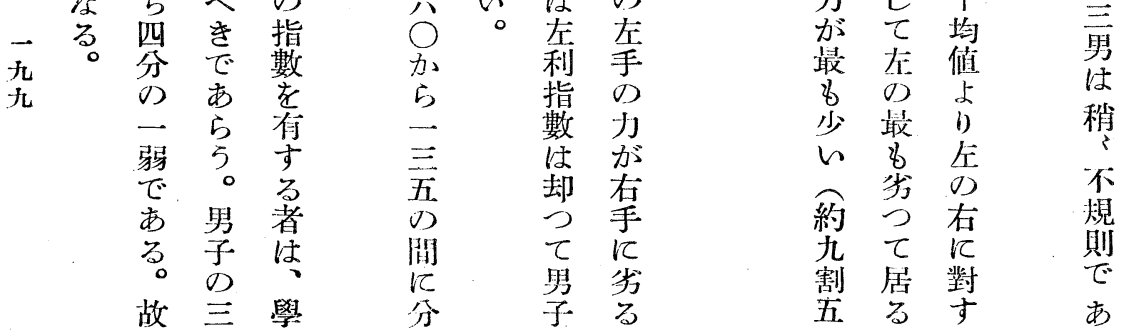


第五琵捯力左利指數分布表

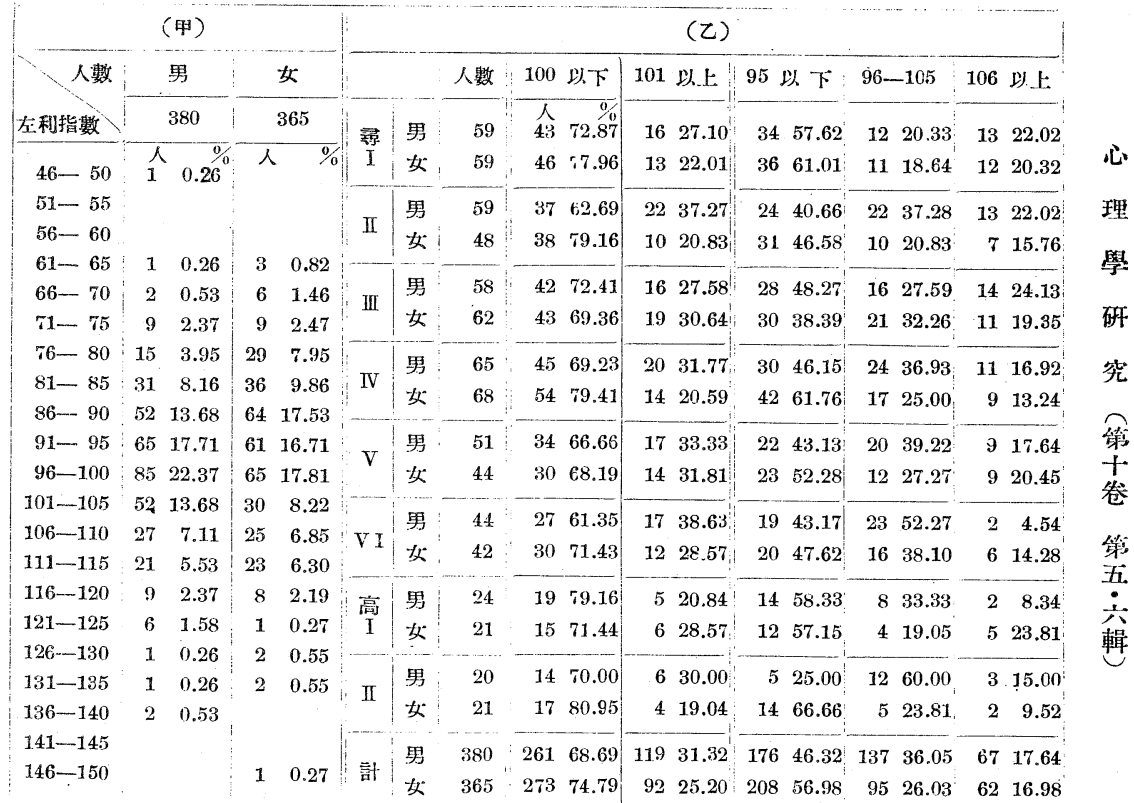

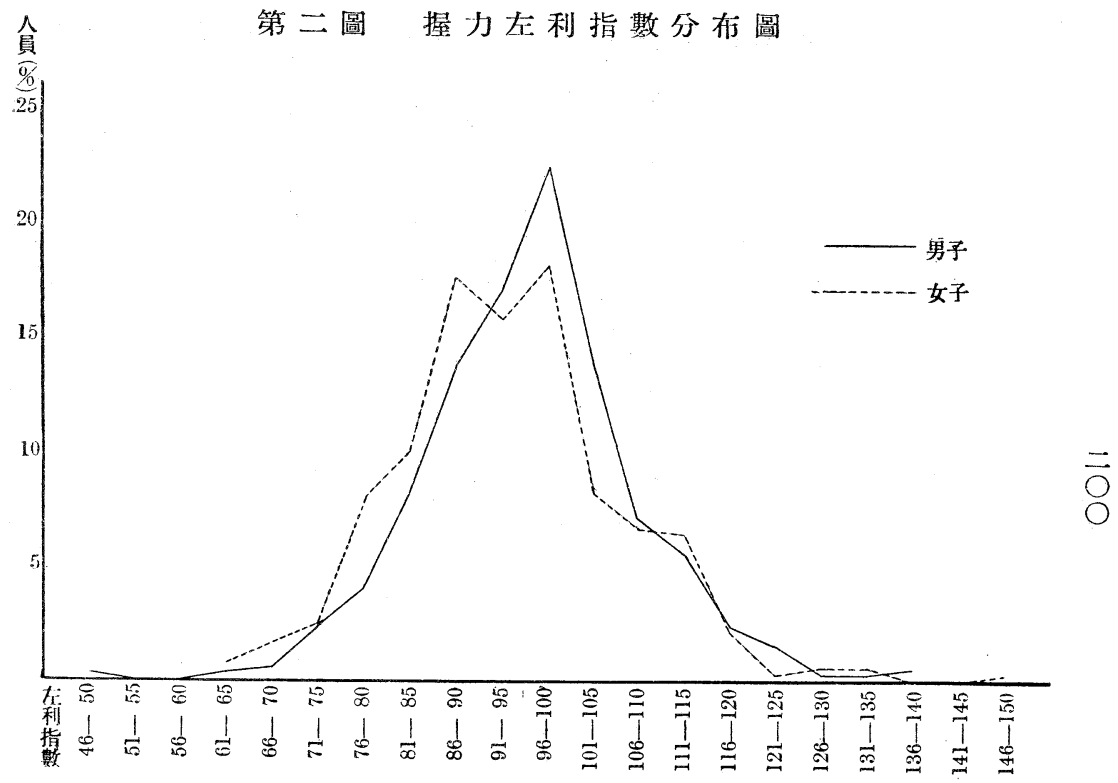


第六表 各學年兒童握力左利指數平均

\begin{tabular}{|c|c|c|c|c|c|c|c|c|}
\hline & 顬 I & II & III & IV & V & VI & 高 I & 高 II \\
\hline 男 & 93.75 & 98.22 & 97.21 & 96.60 & 98.36 & 95.09 & 96.52 & 98.38 \\
\hline 女 & 93.34 & 93.62 & 97.73 & 93.48 & 95.75 & 95.51 & 94.46 & 92.83 \\
\hline
\end{tabular}

万明

庤な 指

利 る 數

は左九

男利 宍

女文加

同 三

率憵五

亦分迄

的

研

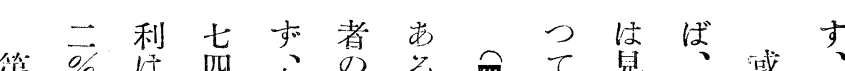

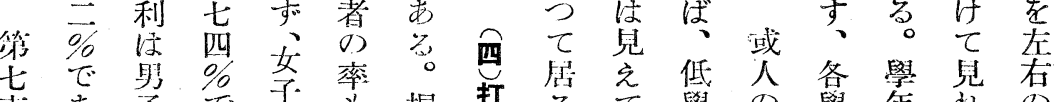

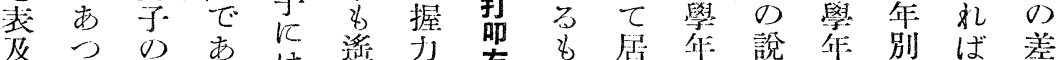

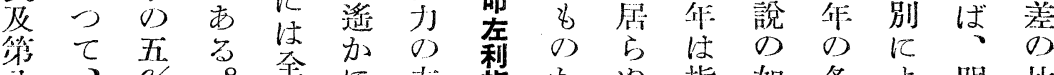

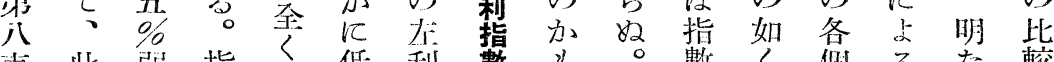

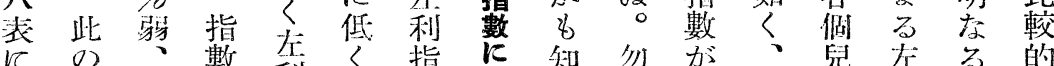

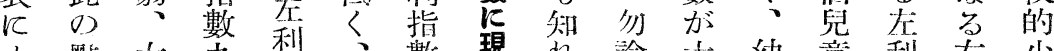

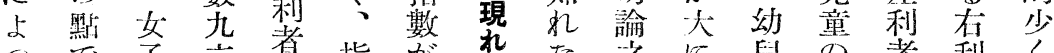

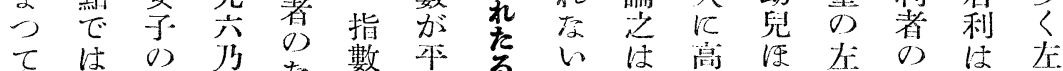

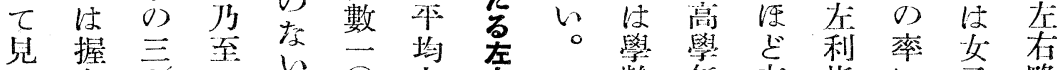

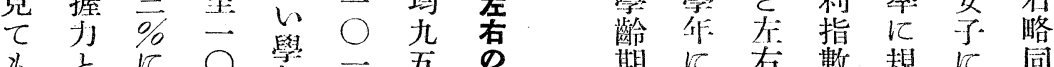

女采光

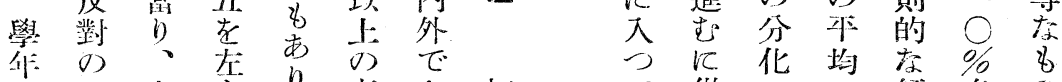

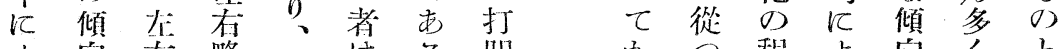

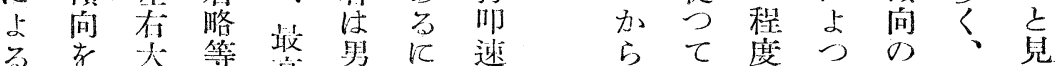

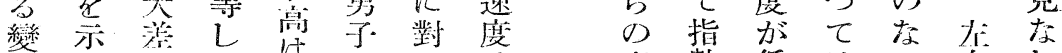

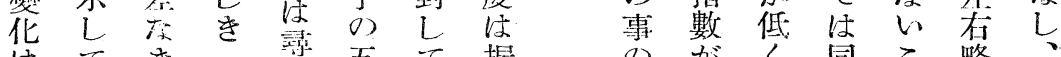

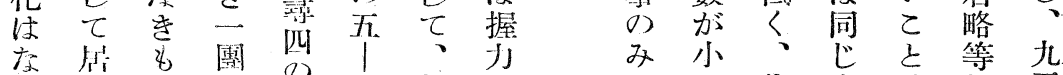

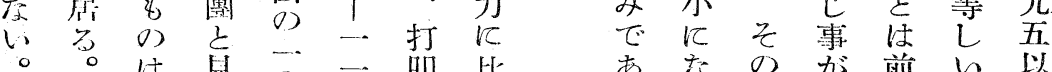

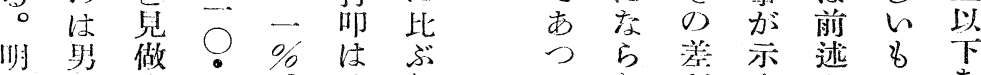

椟等

万り 三杂罗五代、け少狆通は明

有一分\%少少、或机山て少男な

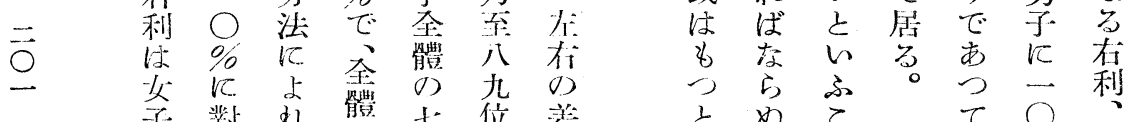

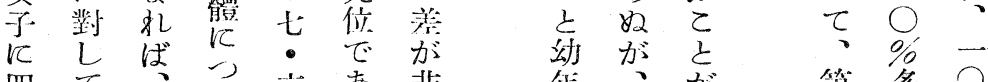

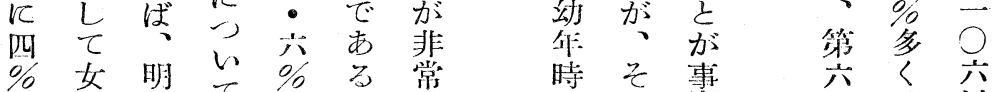

多㚣 明て

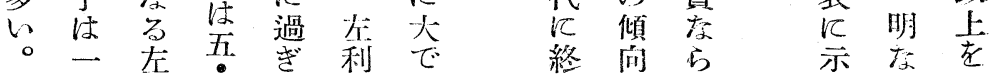


第七表打吒左利指數分布表

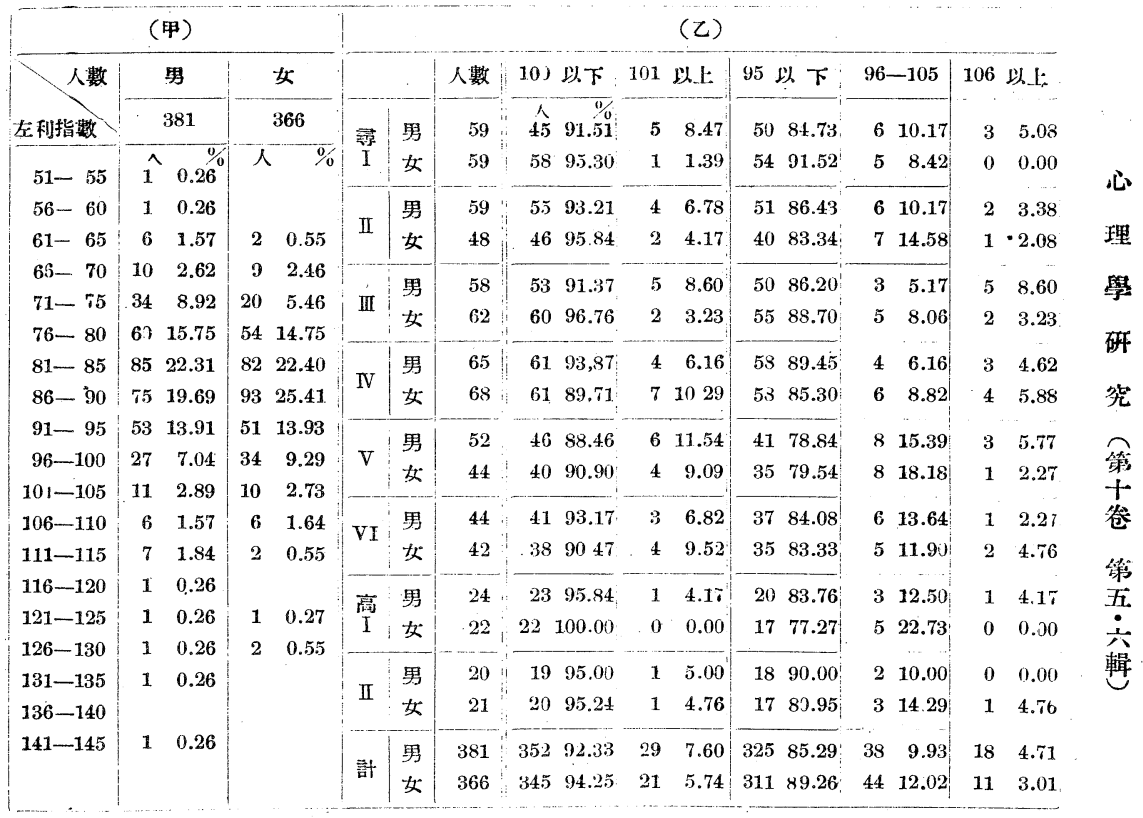

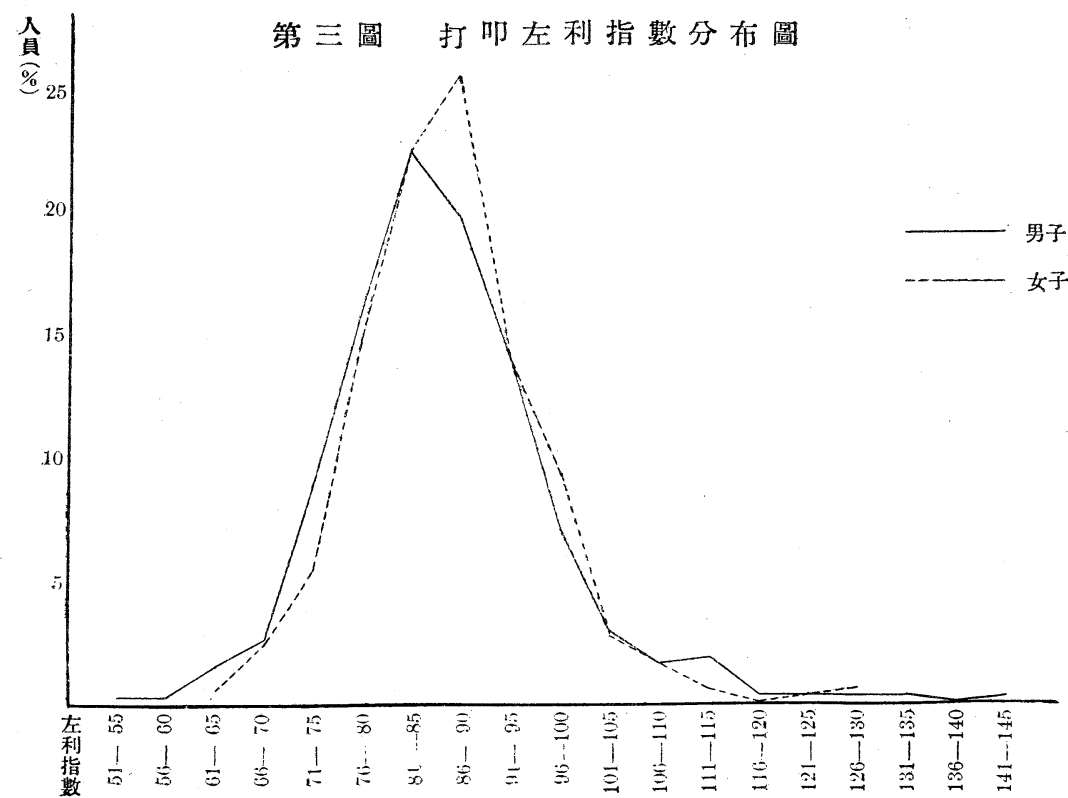


897

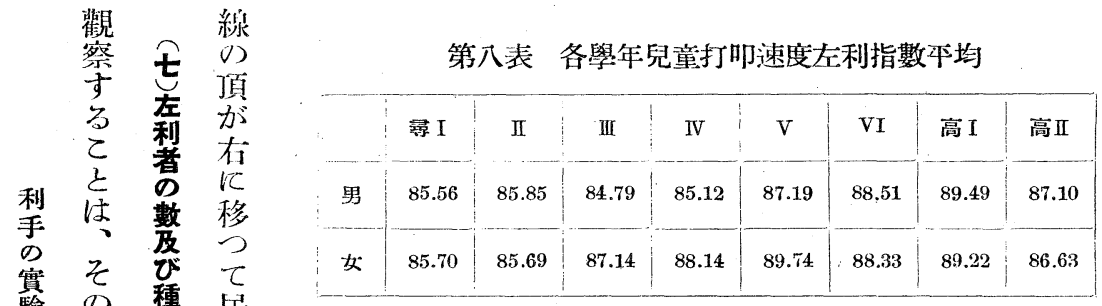

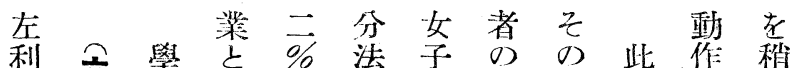

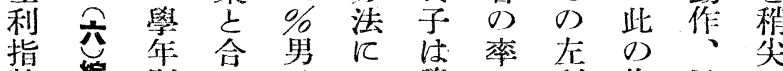

合筫 利

思老左

不利

明の

な閣

ら 題

し は

当㑬

乙人

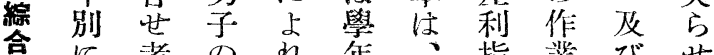

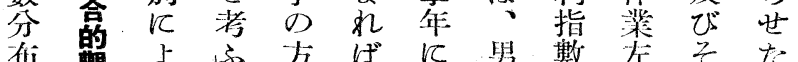

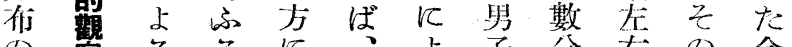

察

之

で型

あ の

る 間

殊䔔

爿

る る

左時多明 b枋能前屬

態利に心在七學の率後の

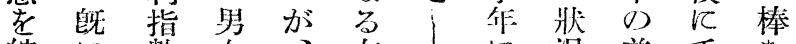

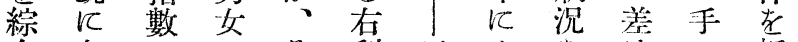

合各 $の$ の

的項本差のは一り示、往み

几自均飞差女 $\%$ - 寸 丁復上

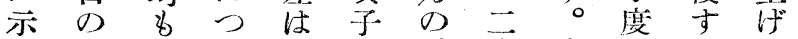

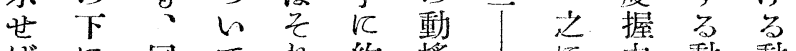

ばに同て狆約播!に少動動

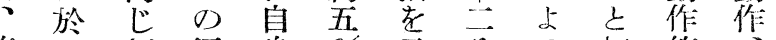

にあ

左方

利 が

第穴傾同身\% 示公つ打等

在故

利

之偑

D) 人

問孝

題 離

の れ

如た握全體

产

五述向已点 L \% て

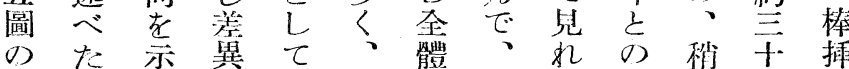

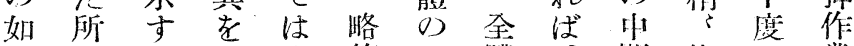

くで。示大等一體、间複に业

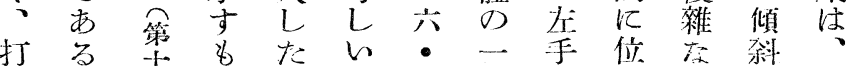

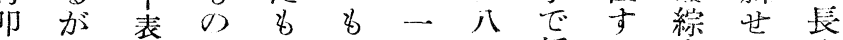

棒 照 䚁

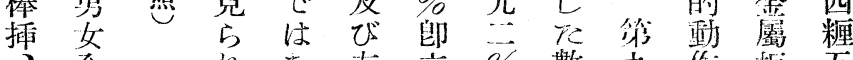

握 體

水疼交 $\%$ 數九作板五

互體 順

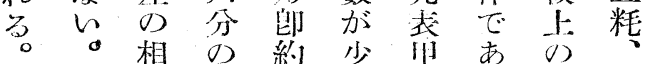

反本䇰作

均均業

傾公数

傾占分對

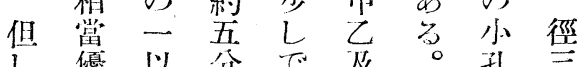

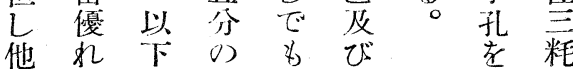

$\begin{array}{lll}\text { 向 } & \text { 等 } & \text { す } \\ \text { を } & \text { 曲 る }\end{array}$

○るで一有第

狙 飞

種当市江乎四

$? \tau$

のは。優は

塖网端 
第九表棒捚左利指數分布表

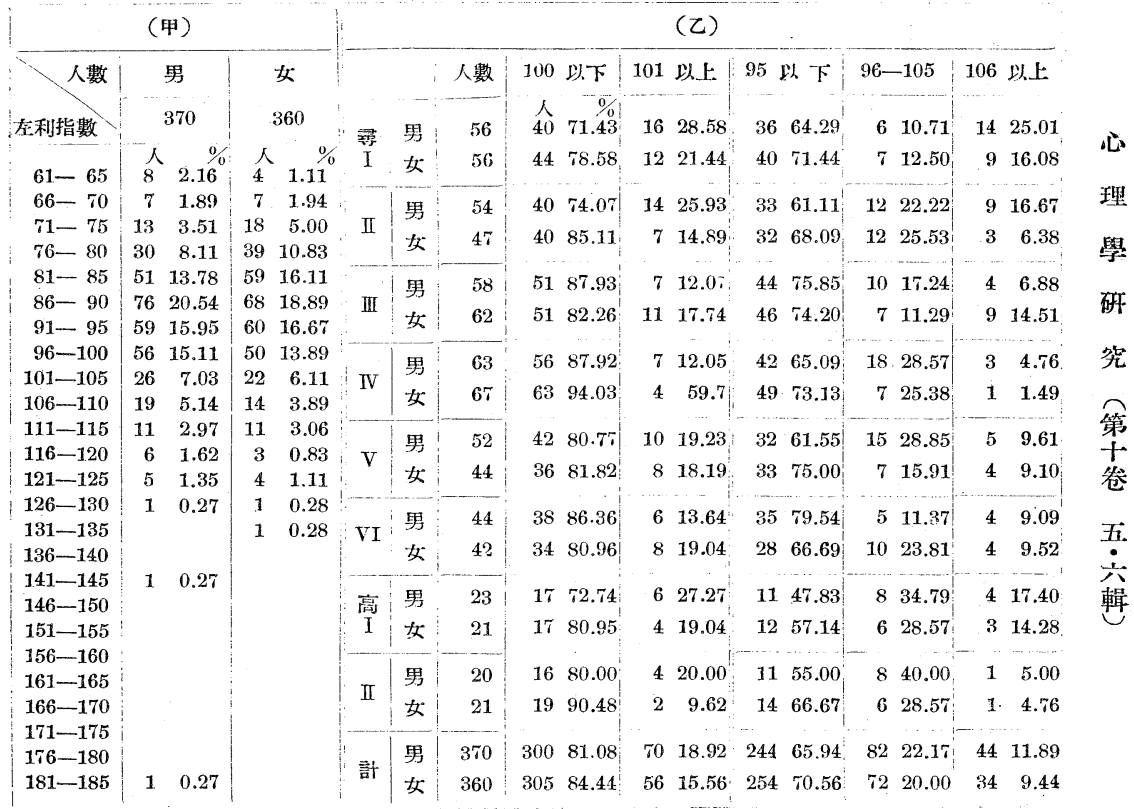

第四圖棒插左利指孉分布圖

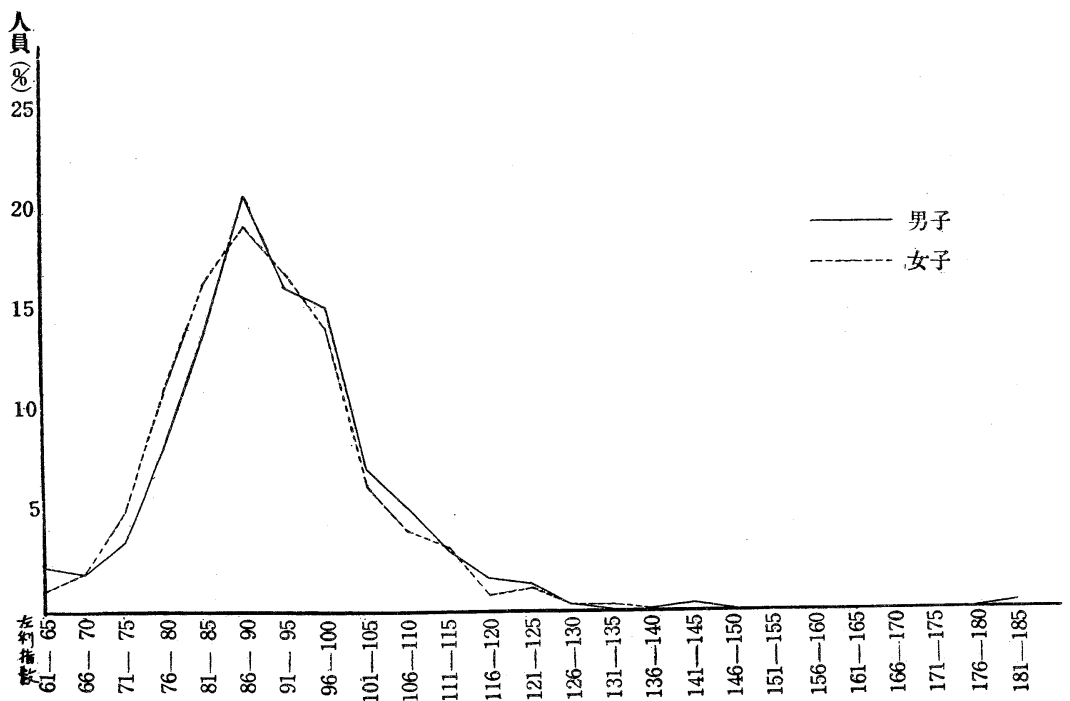


第十表 各學年兒童棒插左利指數平均

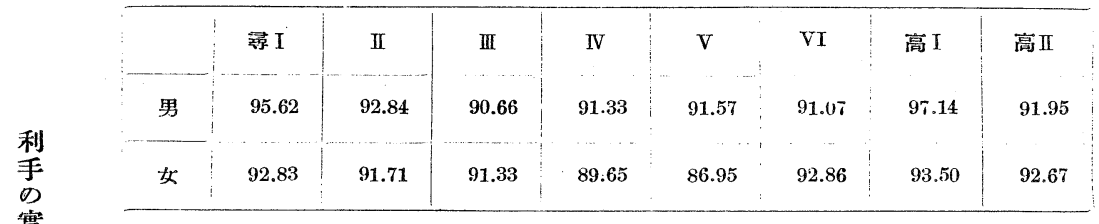

第五圖三種作業左利指數分布圖

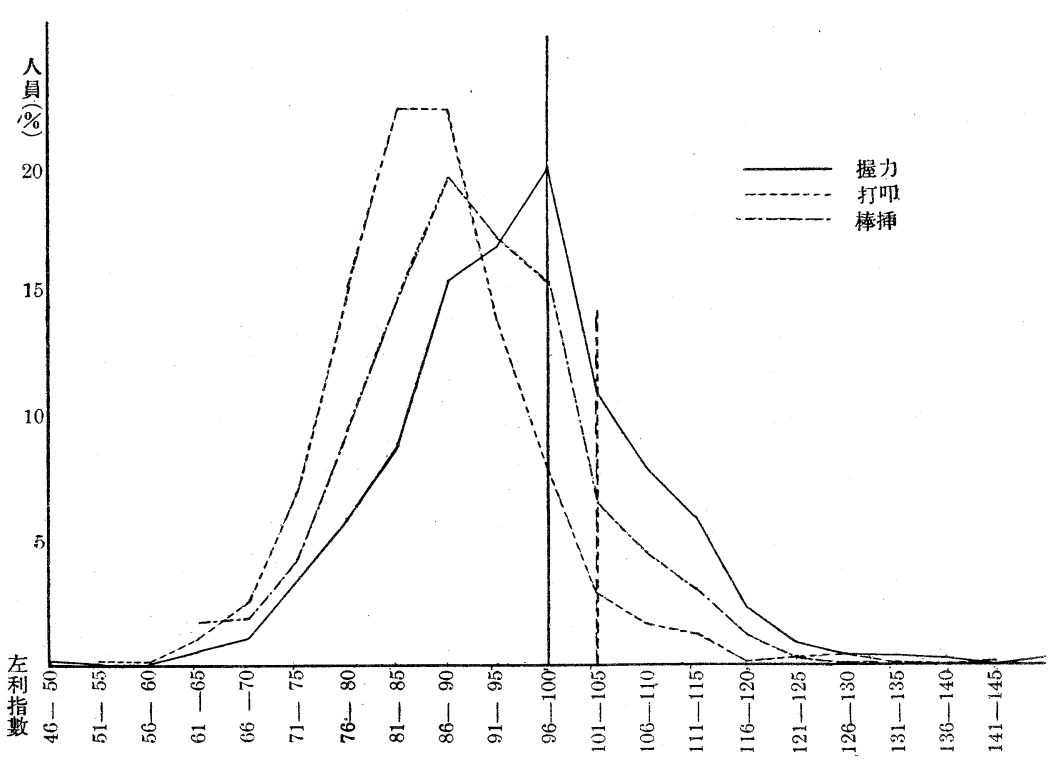

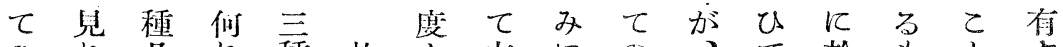

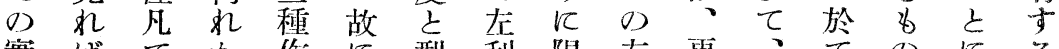

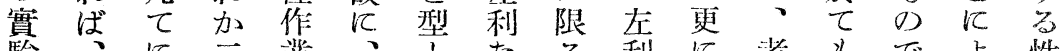

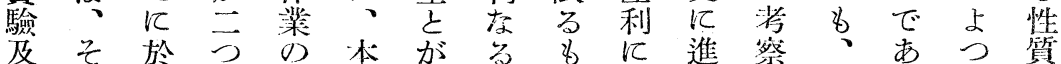

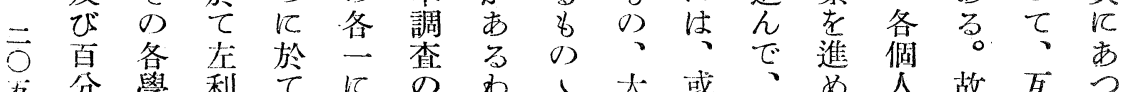

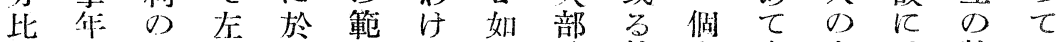

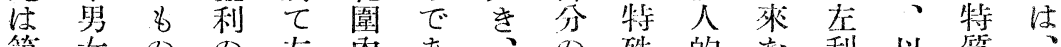

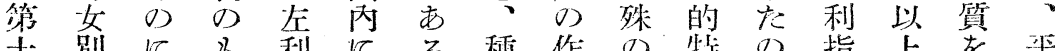

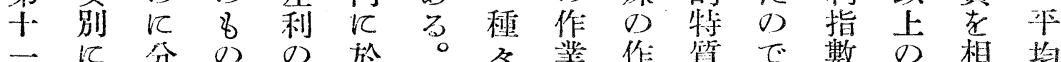
表つ 分 の、占

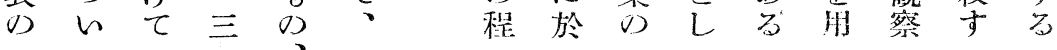




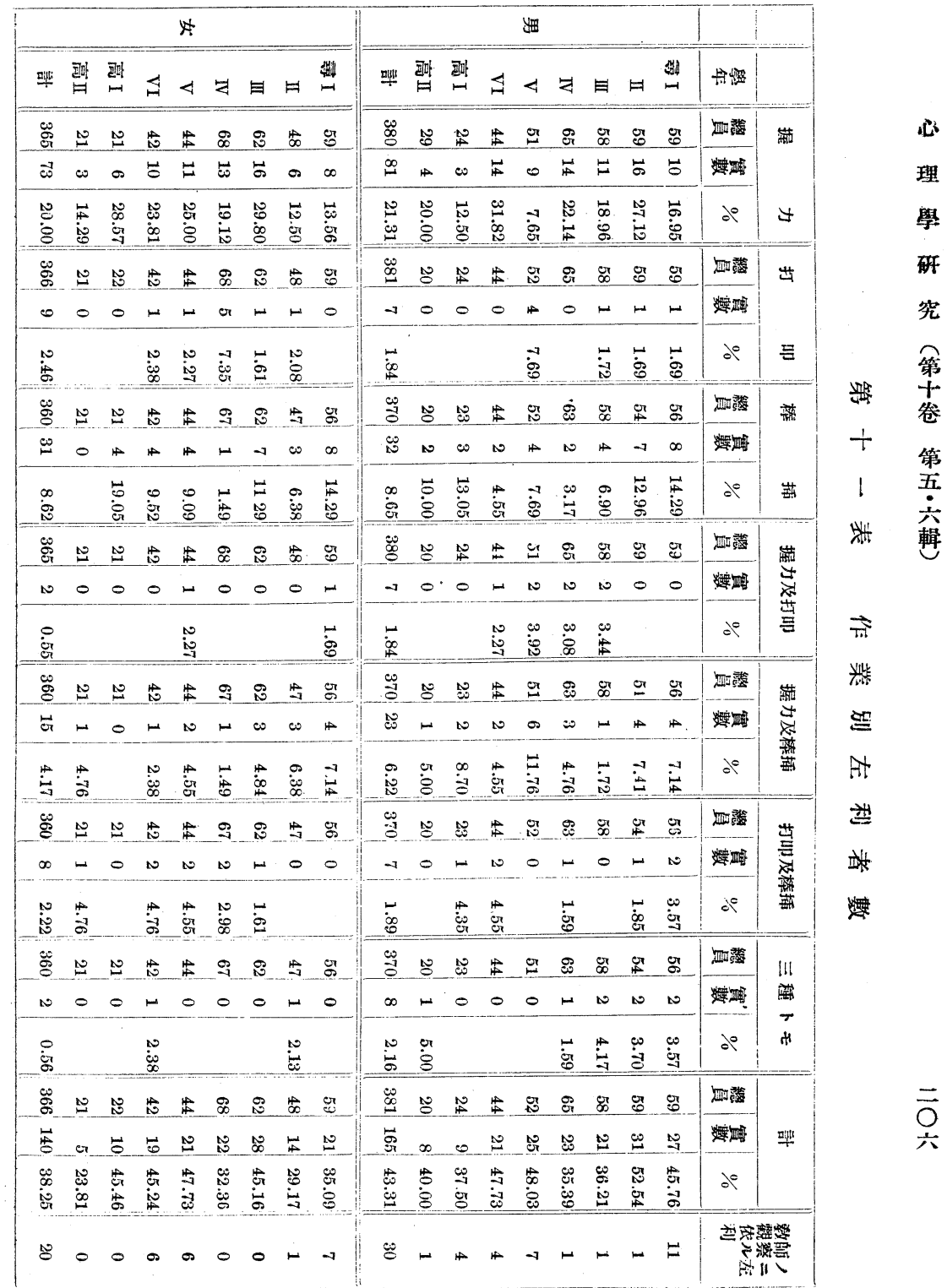


第十二表(甲) 敎師ノ報告 $=\exists ル$ 左利兒童(男子)

\begin{tabular}{|c|c|c|c|c|c|c|c|c|c|c|}
\hline 學 年 & $\begin{array}{l}\text { 代 名 } \\
\text { 番 號 }\end{array}$ & $\begin{array}{l}\text { 左利 =關 スル } \\
\text { 記 述 或 項 }\end{array}$ & $\begin{array}{l}\text { 握 } \\
\text { 左 } \\
\text { 石 }\end{array}$ & $\begin{array}{l}\text { 力 } \\
\text { 指 數 }\end{array}$ & $\begin{array}{l}\text { 打 } \\
\text { 左 } \\
\text { 公 }\end{array}$ & $\begin{array}{l}\text { 㠲 } \\
\text { 旨 } \\
\text { 數 }\end{array}$ & $\begin{array}{l}\text { 棒 } \\
\text { 左 } \\
\text { 右 }\end{array}$ & $\begin{array}{l}\text { 插 } \\
\text { 指 數 }\end{array}$ & 用鉄指數 & $\begin{array}{l}\text { 學科成 } \\
\text { 結平均 }\end{array}$ \\
\hline \multirow[t]{11}{*}{ 灵 I } & 588 & 0 & $\frac{9.5}{12}$ & 79.17 & $\frac{92}{105}$ & 87.62 & $\frac{21}{22}$ & 95.45 & 0 & 9 \\
\hline & 577 & 0 & $\frac{13}{13}$ & 100 & $\frac{85}{107}$ & 79.44 & $\frac{18}{19}$ & 94.74 & 85 & 9 \\
\hline & 567 & 0 & $\frac{12}{-15}$ & 80.00 & $\frac{87}{110}$ & 79.09 & $\frac{17}{25}$ & 68.00 & 62 & 9 \\
\hline & 564 & 石投，重イモノ & $\frac{11.5}{11}$ & 95.38 & $\frac{73}{107}$ & 68.22 & $\begin{array}{l}19 \\
21\end{array}$ & 90.47 & 72.73 & 5 \\
\hline & 559 & 石投，重イモノ & $\frac{11.5}{111}$ & 104.55 & $\frac{126}{113}$ & 111.50 & $\frac{24}{13}$ & 184.62 & 500 & 9 \\
\hline & 557 & 不投，重イモ， & $\frac{11}{12}$ & 91.67 & $\frac{89}{105}$ & 84.76 & $\frac{16}{23}$ & 69.57 & 62.5 & 8 \\
\hline & 554 & 重イモノ & $\frac{9}{12}$ & 75.00 & $\frac{84}{102}$ & 82.35 & $\frac{19}{21}$ & 90.47 & 52.63 & 7 \\
\hline & 552 & 石投，重イモノ & $\frac{11}{15}$ & 73.33 & $\frac{83}{112}$ & 74.11 & $\frac{20}{22}$ & 90.91 & 15.79 & 7 \\
\hline & 550 & 石投, 重イモノ & $\frac{13}{13}$ & 100 & $\frac{\varepsilon 5}{91}$ & 86.41 & $\frac{15}{22}$ & 68.18 & 30.00 & 7 \\
\hline & 549 & 石投 & $\frac{11}{10.5}$ & 104.76 & $\frac{87}{103}$ & 84.47 & $\frac{19}{24}$ & 79.17 & 142.86 & 5 \\
\hline & 547 & 石投，重イモノ & $\frac{12}{14}$ & 85.71 & $\frac{83}{115}$ & 72.17 & $\frac{23}{25}$ & 92.00 & 0 & 9 \\
\hline II & 497.4 & 0 & - & - & - & - & & - & - & 7 \\
\hline III & 356 & 0 & $\frac{33.5}{12}$ & 112.50 & $\frac{84}{78}$ & 107.69 & $\frac{22}{20}$ & 110.00 & 1200 & 5 \\
\hline IV & 205 & 全 部 & $\frac{13}{12.5}$ & 104.00 & $\frac{157}{109}$ & 144.04 & $\frac{23}{23}$ & 100 & $\frac{16}{0}$ & 7 \\
\hline $\mathrm{V}$ & 120 & ボール投 & $\frac{20.5}{19}$ & 107.89 & $\frac{134}{153}$ & 87.58 & $\frac{26}{26}$ & 100 & 50 & 5.5 \\
\hline & 118 & ボール投 & $\frac{19.5}{18.5}$ & 105.41 & $\frac{118}{150}$ & 78.67 & $\frac{23}{23}$ & $1 \mathrm{C} 0$ & 35 & 8.6 \\
\hline & 117 & 鉛筆ヨ刢ルトキ & $\frac{17.5}{16}$ & 109.38 & $\frac{138}{129}$ & 106.98 & $\frac{17}{26}$ & 65.38 & 133.33 & 5.6 \\
\hline & 99 & ボール投 & $\begin{array}{l}16 \\
16\end{array}$ & 100 & $\frac{128}{142}$ & 90.14 & $\frac{22}{20}$ & 110.00 & 45 & 3.7 \\
\hline & 98 & $\begin{array}{l}\text { 鉛箻ヨ刞ルトキ， } \\
\text { 投 }\end{array}$ & $\begin{array}{r}24 \\
-20\end{array}$ & 120.00 & $\frac{136}{137}$ & 99.27 & $\frac{32}{31}$ & 103.23 & 107.14 & 6.8 \\
\hline & 97 & ボール投 & $\frac{20}{18}$ & 111.11 & $\frac{139}{147}$ & 94.56 & $\frac{28}{27}$ & 103.70 & 80.95 & 5.0 \\
\hline & 89 & 䈾, ボール投 & $\frac{15.5}{15}$ & 103.33 & $\frac{136}{137}$ & 99.27 & $\frac{27}{25}$ & 108.00 & 237.50 & 5.1 \\
\hline VI & 29 & ボール投 & $\frac{21}{22.5}$ & 93.33 & $-\frac{151}{138}$ & 109.42 & $\begin{array}{l}25 \\
24\end{array}$ & 104.17 & 12.5 & 5 \\
\hline & 16 & $\begin{array}{l}\text { 物ヨ食ぶルトキ } \\
\text { 左デモッ }\end{array}$ & $\begin{array}{l}22 \\
21\end{array}$ & 104.76 & $\frac{144}{152}$ & 94.74 & $\begin{array}{l}35 \\
33\end{array}$ & 106.06 & 271.43 & 7 \\
\hline & 11 & 䉕以外金部左: & $\begin{array}{l}21 \\
22\end{array}$ & 95.45 & $\begin{array}{r}149 \\
144\end{array}$ & 103.47 & $\begin{array}{l}35 \\
30\end{array}$ & 116.67 & 155.00 & 9 \\
\hline
\end{tabular}




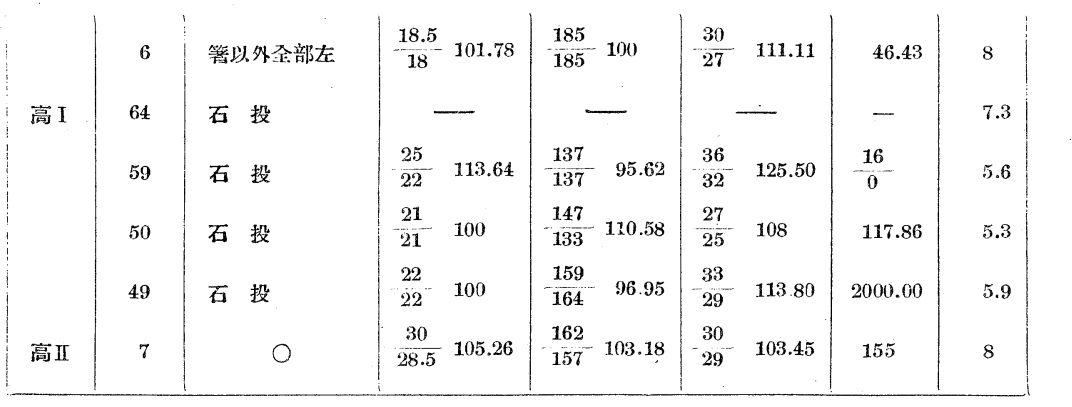

第十二表(乙) 呚師)報告二ヨル左利兒童(女子)

\begin{tabular}{|c|c|c|c|c|c|c|c|c|c|c|}
\hline 嚳 年 & $\begin{array}{l}\text { 代 各 } \\
\text { 貔 號 }\end{array}$ & $\begin{array}{l}\text { 庄利二關 スル } \\
\text { 部逝 项 }\end{array}$ & $\begin{array}{l}\text { 握 } \\
\text { 有 } \\
\text { 不 }\end{array}$ & $\begin{array}{l}\text { 力 } \\
\text { 指 數 }\end{array}$ & $\begin{array}{l}\text { 打 } \\
\text { 右 } \\
\text { 右i }\end{array}$ & $\begin{array}{l}\text { 叮 } \\
\text { 指 數 }\end{array}$ & $\begin{array}{l}\text { 檴 } \\
\text { 左 } \\
1 i\end{array}$ & $\begin{array}{l}\text { 搟 } \\
\text { 指 數 }\end{array}$ & 用銭指數 & $\begin{array}{l}\text { 學科成 } \\
\text { 續本均 }\end{array}$ \\
\hline \multirow[t]{7}{*}{ I } & 628 & 0 & $\begin{array}{l}9 \\
9\end{array}$ & 100 & $\frac{81}{90}$ & 90.00 & $\begin{array}{l}18 \\
20\end{array}$ & 90.00 & 500.00 & 6 \\
\hline & 625 & マリ投ゲ & $\begin{array}{c}8 \\
12\end{array}$ & 66.67 & $\begin{array}{l}122 \\
138\end{array}$ & 88.41 & $\begin{array}{l}23 \\
24\end{array}$ & 95.83 & 2.5 & 9 \\
\hline & 624 & マリ投ゲ & $\begin{array}{l}6 \\
7\end{array}$ & 85.65 & $\frac{87}{100}$ & 87.00 & $\frac{18}{17}$ & 105.88 & 0 & 6 \\
\hline & 622 & 扫投, 重イモ & $\begin{array}{l}9.5 \\
8.5\end{array}$ & 111.76 & $\frac{97}{129}$ & 75.19 & $\begin{array}{l}20 \\
21\end{array}$ & 75.00 & 71.43 & 6 \\
\hline & 616 & ア甸投, 重イモ & $\frac{8}{9.5}$ & 84.21 & $\begin{array}{l}105 \\
124\end{array}$ & 84.68 & $\frac{14}{17}$ & 82,35 & 84.62 & 5 \\
\hline & 615 & アリ投, 重イモ & $\begin{array}{l}7 \\
8\end{array}$ & 87.50 & $\begin{array}{l}105 \\
124\end{array}$ & 8468 & $\frac{18}{20}$ & 90.00 & 36.84 & 8 \\
\hline & 613 & マリ投ゲ & $\frac{7}{7.5}$ & 93.33 & $\frac{92}{98}$ & 93.88 & $\frac{24}{21}$ & 114.29 & 92.31 & 8 \\
\hline II & 516 & 0 & $\begin{array}{l}9 \\
8\end{array}$ & 112.50 & $\frac{124}{121}$ & 102.48 & $\frac{26}{22}$ & 118.18 & 250.00 & 5 \\
\hline \multirow[t]{6}{*}{ V } & 180 & 箸 & $\frac{18}{17}$ & 105.88 & $\frac{133}{154}$ & 86.36 & 36 & 83.84 & 48.15 & 8 \\
\hline & 169 & ボール投, 銶 & $\frac{12.5}{5}$ & 113.14 & $\begin{array}{l}133 \\
141\end{array}$ & 97.87 & $\begin{array}{l}24 \\
26\end{array}$ & 92.31 & 71.88 & 6 \\
\hline & 166 & 鋏 & $\begin{array}{l}14 \\
13\end{array}$ & 107.70 & $\begin{array}{l}136 \\
135\end{array}$ & 100.74 & $\frac{29}{26}$ & 111.54 & 225.00 & 9 \\
\hline & 155 & 篲, 錸,ボール投 & $\frac{15}{15}$ & 100 & $\begin{array}{l}147 \\
138\end{array}$ & 106.52 & $\begin{array}{l}23 \\
25\end{array}$ & 92.00 & 160.00 & 7 \\
\hline & 150 & 鉄 & $\frac{11.5}{10}$ & 115.00 & $\begin{array}{l}131 \\
124\end{array}$ & 105.6 .5 & $\begin{array}{l}26 \\
27\end{array}$ & 96.30 & 115.80 & 6 \\
\hline & 144 & 鏯 & $\frac{11}{11.5}$ & 95.65 & $\begin{array}{l}127 \\
120\end{array}$ & 105.83 & $\begin{array}{l}21 \\
19\end{array}$ & 110.53 & 75 & 3 \\
\hline \multirow[t]{6}{*}{ VI } & 84 & 打ツ, 飯シッヶ & $\frac{19}{18}$ & 105.56 & $\begin{array}{l}138 \\
141\end{array}$ & 97.87 & $\begin{array}{l}29 \\
29\end{array}$ & 100 & 100 & 9 \\
\hline & 77 & 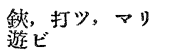 & 18 & 112.50 & $\begin{array}{l}141 \\
136\end{array}$ & 103.68 & $\begin{array}{l}30 \\
28\end{array}$ & 107.14 & 352.94 & 5 \\
\hline & 75 & $\begin{array}{l}\text { 鋏, 打ッ, マリ } \\
\text { ナゲ }\end{array}$ & $\begin{array}{l}16 \\
15\end{array}$ & 106.67 & $\begin{array}{l}149 \\
168\end{array}$ & 88.69 & $\begin{array}{l}30 \\
27\end{array}$ & 111.11 & 250 & 5 \\
\hline & 67 & 鋏, マリ遊ビ & $\frac{16}{15.5}$ & 103.23 & $\begin{array}{l}134 \\
152\end{array}$ & 83.16 & $\begin{array}{l}27 \\
31\end{array}$ & 87.10 & 270 & 7 \\
\hline & 61 & $\begin{array}{l}\text { マリッキ, 御手 } \\
\text { 正 }\end{array}$ & $\begin{array}{l}16 \\
16\end{array}$ & 100 & $\begin{array}{l}132 \\
131\end{array}$ & 100.76 & $\begin{array}{l}30 \\
29\end{array}$ & 103.45 & 103.92 & 6 \\
\hline & 51 & 磢, 打ツ & $\begin{array}{l}18 \\
18\end{array}$ & 100 & $\begin{array}{l}159 \\
166\end{array}$ & 95.78 & $\begin{array}{l}34 \\
33\end{array}$ & 103.03 & 200 & 9 \\
\hline
\end{tabular}




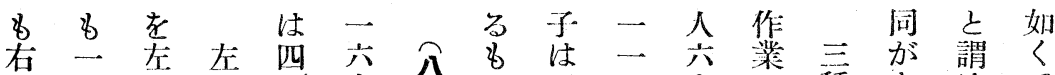

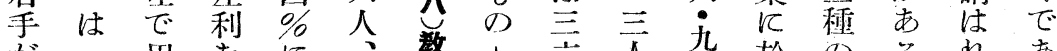

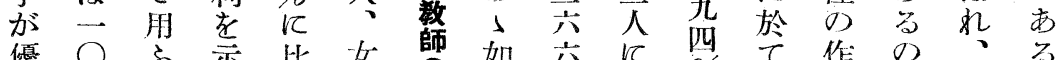
優 $\bigcirc$ 示比文留 如六

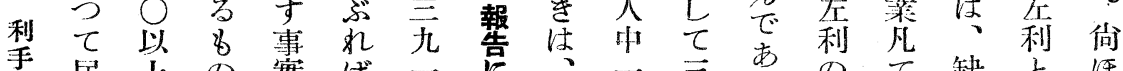

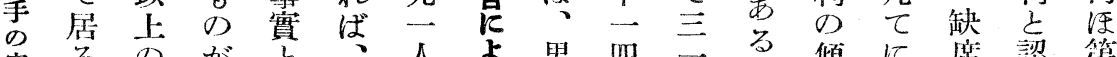
實るの がを、人点思四二方傾に席認第

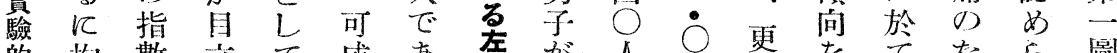

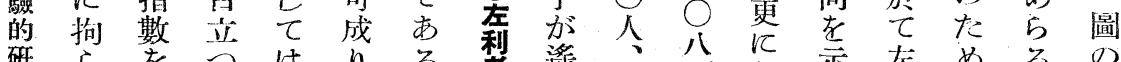

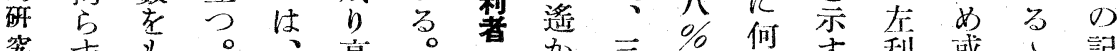

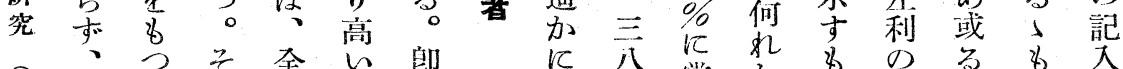

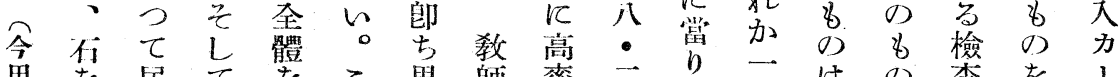

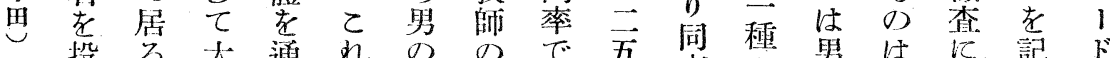

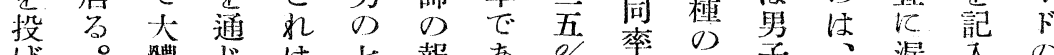

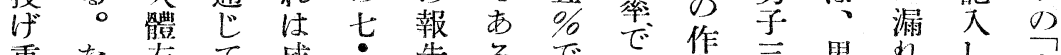

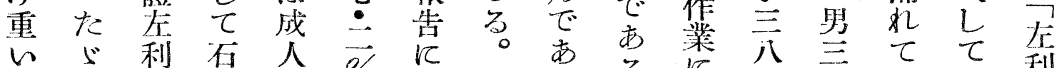
物韋 指 石人

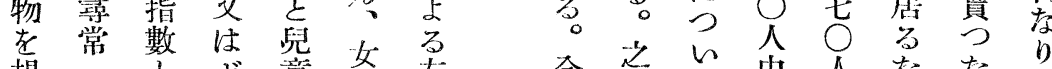
提茂亡 万生致儿兌の

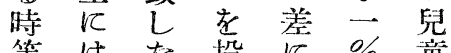
等は投瓜 \% 童 に男名げ起での 左女文因 あ 數 手共がの L? は 老多にてて思

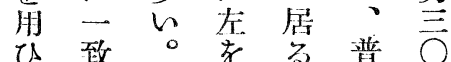

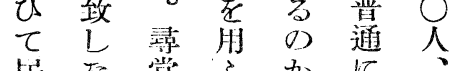

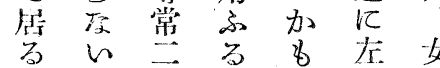
漙名华生名知利者 一が以が染の人 盟多上多い率で 川以应以。上亦 指。男品?

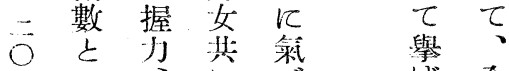

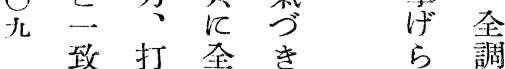
致打全き部占調

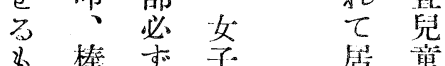

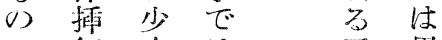
名们之䤲惐罗

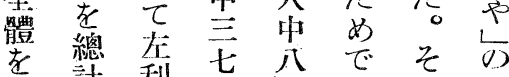

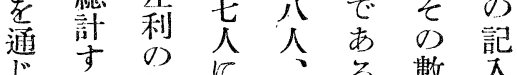

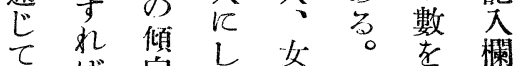

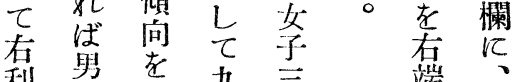
利者走九辛端擔 者はす寸相閏 率公名五人教

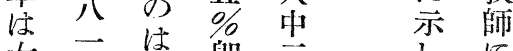

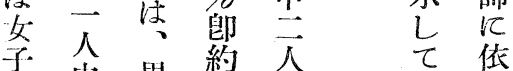
飞男約人賴 量 永 五 0 ○

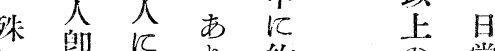
毁飞 b 約常 四 $气$ 四 場生 程 气立倍 合 活 凡 三三系市 生に

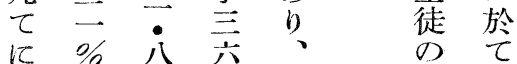
於沱 $\%$ 五何 總立

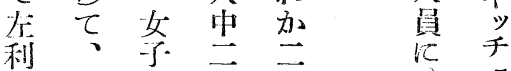
李细五可不品 


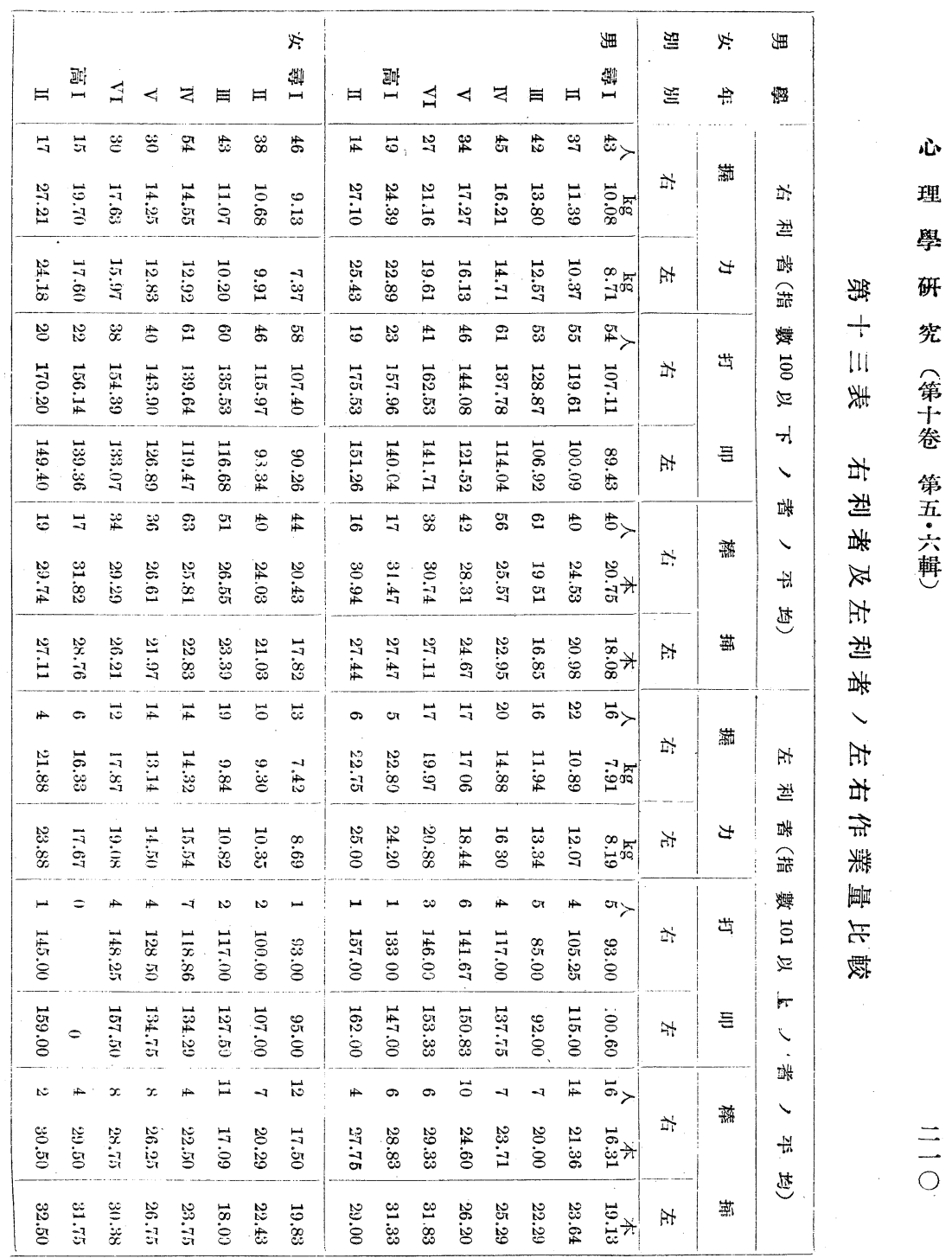




\begin{tabular}{|c|c|c|c|c|c|c|c|c|c|}
\hline $\begin{array}{l}\text { 圆 } \\
\text { 正 }\end{array}$ & $\begin{array}{c}111 \\
1 \\
111 \\
1\end{array}$ & $\begin{array}{l}6 \\
\text { 且 } \\
1 \\
11\end{array}$ & $\begin{array}{l}11 ! \\
H\end{array}$ & $\begin{array}{l}11 \\
y\end{array}$ & $\begin{array}{c}14 \\
11 \\
1\end{array}$ & $\begin{array}{c}1 \\
y \\
1\end{array}$ & $\begin{array}{l}11 \\
26\end{array}$ & 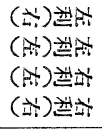 & 叫出 \\
\hline 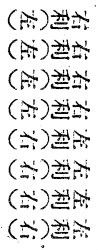 & 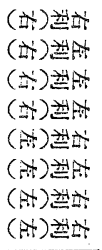 & 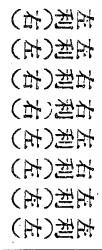 & 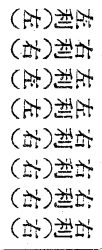 & 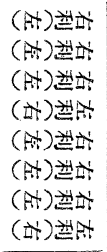 & 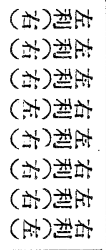 & 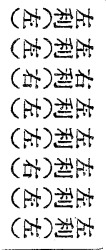 & 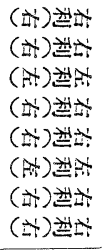 & $\begin{array}{l}11 \\
1 \\
21 \\
11 \\
\mathbb{E} \\
111 \\
11 \\
1\end{array}$ & 개아 \\
\hline 로 고 & E 111 & F 11 然 & $\Leftrightarrow 1$ 数 & $\vec{F}$ 四 & ह 111 & हE $\|$ 将 & $\vec{E} 1$ 嘕 & & \\
\hline \multicolumn{4}{|c|}{$x$} & \multicolumn{4}{|c|}{ 凅 } & & \\
\hline
\end{tabular}

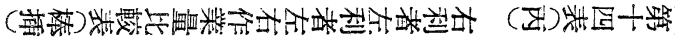

\begin{tabular}{|c|c|c|c|c|c|c|c|c|c|}
\hline $\begin{array}{l}! 1 \\
4 !\end{array}$ & $\begin{array}{l}H ! \\
11\end{array}$ & $\begin{array}{l}y \\
1 \\
1\end{array}$ & $\begin{array}{l}i \\
+\end{array}$ & $\begin{array}{l}11 \\
2 t\end{array}$ & $\begin{array}{l}21 \\
1 \\
1\end{array}$ & $\begin{array}{l}2 t \\
1 \\
1\end{array}$ & 1 & 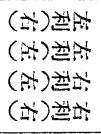 & 매웅 \\
\hline 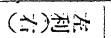 & (At) 페네 & 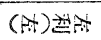 & 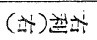 & (A) 塑到 & 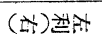 & 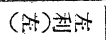 & 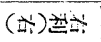 & 11 & \\
\hline & 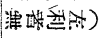 & $(A)$ 然柆 & 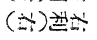 & 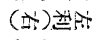 & (At) 恝至 & (At) 些A & （场）娄会 & 1 & 믐? \\
\hline (m) 㐘恶 & 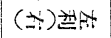 & (场)贺公 & 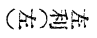 & (At) 然站 & 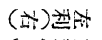 & (A) 些At & (式)些会 & 决 & \\
\hline (A) 热式 & 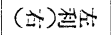 & $(A)$ 然A & 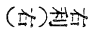 & $(A+)$ 誌椋 & (iㅏ)些式 & 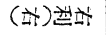 & $(A)$ 些 & $H$ & \\
\hline (i) & (A) & (N) 恝N & 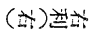 & 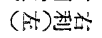 & (t) & (At) 㷛A & 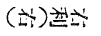 & I & \\
\hline (A) 吾立 & (i) 然到 & (At) 垪 & (诗)些市 & 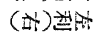 & $(A)$ & (N) 然背 & (A) 整至 & III & \\
\hline 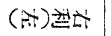 & (ii)想 & $(A)$ 范A & 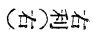 & (A) 部方 & (N) 팬사 & (A) 然 & (咕)至式 & 11 & \\
\hline (A) 尊五 & 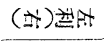 & (At) 랭사 & （部）㷛主 & (A) 然动 & (城)些材 & (A) 然成 & (形) 娄式 & $!$ & 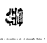 \\
\hline$\vec{k}$ 圆 & E & $\vec{B} \|$ & $\Leftrightarrow 1$ 粘 & 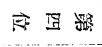 & ह $11 !$ 架 & $\vec{k} \|$ & $\vec{k} \mid$ & & \\
\hline \multicolumn{4}{|c|}{$A$} & \multicolumn{4}{|c|}{$y$} & & \\
\hline
\end{tabular}

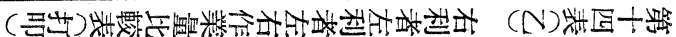

\begin{tabular}{|c|c|c|c|c|c|c|c|c|c|}
\hline 포 & $\begin{array}{c}111 \\
1 \\
111 \\
1\end{array}$ & $\begin{array}{c}1 \\
19 \\
1 \\
11\end{array}$ & $\begin{array}{l}\text { II. } \\
\text { Hil }\end{array}$ & 是 & $\begin{array}{c}\text { Th } \\
1 \\
111\end{array}$ & $\begin{array}{c}\text { TI } \\
1 \\
111\end{array}$ & $H$ & 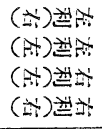 & 매요 \\
\hline 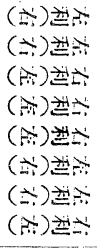 & 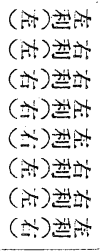 & 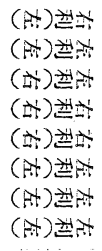 & 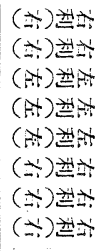 & 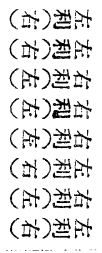 & 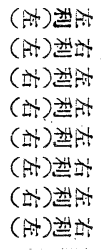 & 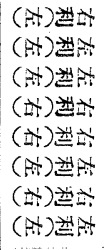 & 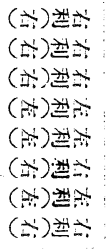 & $\begin{array}{c}1 ! \\
1 \\
\text { 泣 } \\
H ! \\
\text { 포 } \\
1 ! \\
11 \\
1\end{array}$ & stid \\
\hline 타요 & 店 111 & 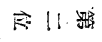 & $\vec{E} \mid$ 路 & 隔国 & $\Leftrightarrow \|$ & $\vec{k} 11$ 雅 & $\vec{k} !$ 掣 & & \\
\hline \multicolumn{4}{|c|}{$x$} & \multicolumn{4}{|c|}{$y$} & & \\
\hline
\end{tabular}

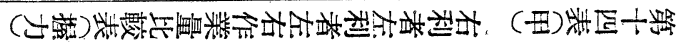




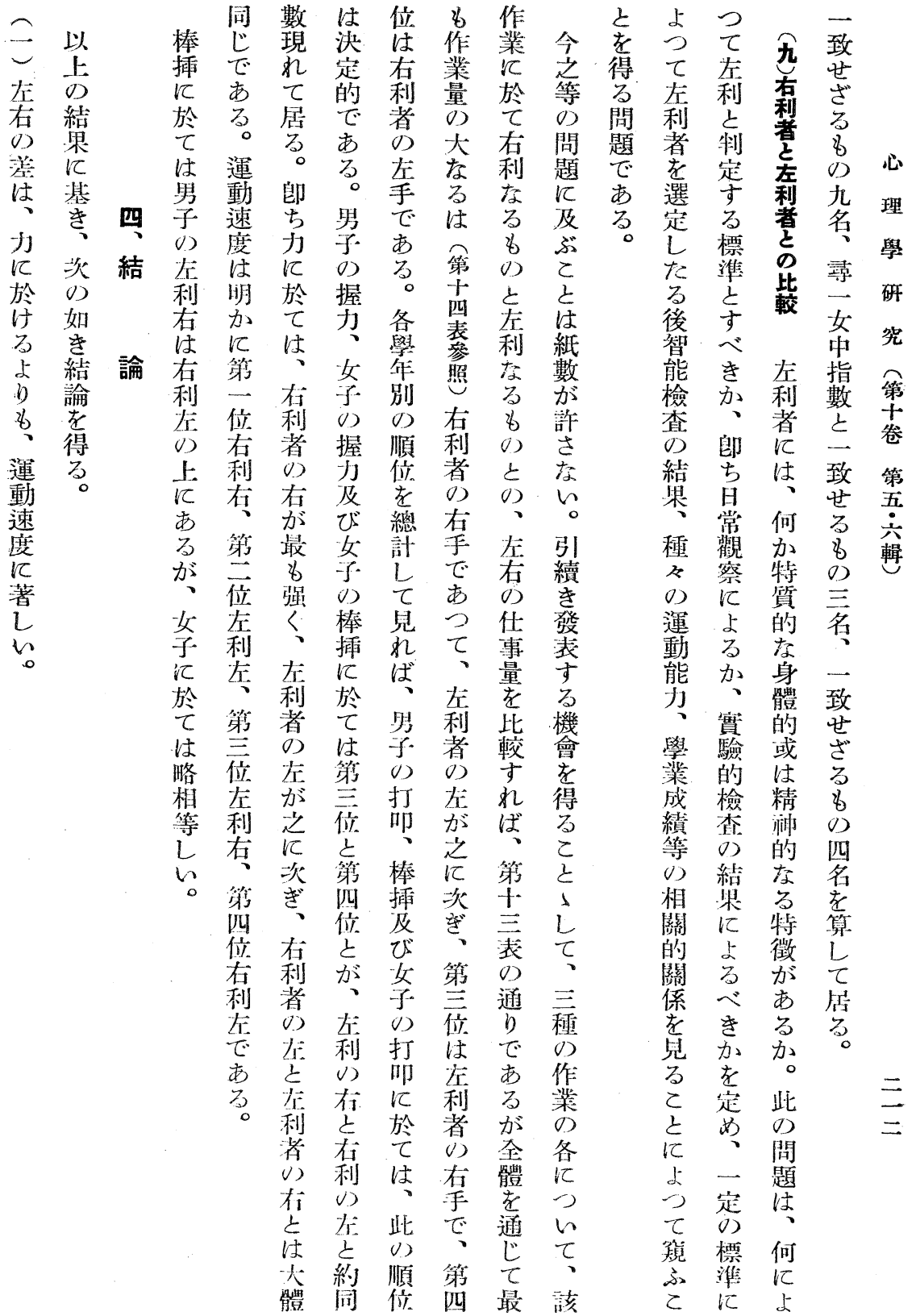




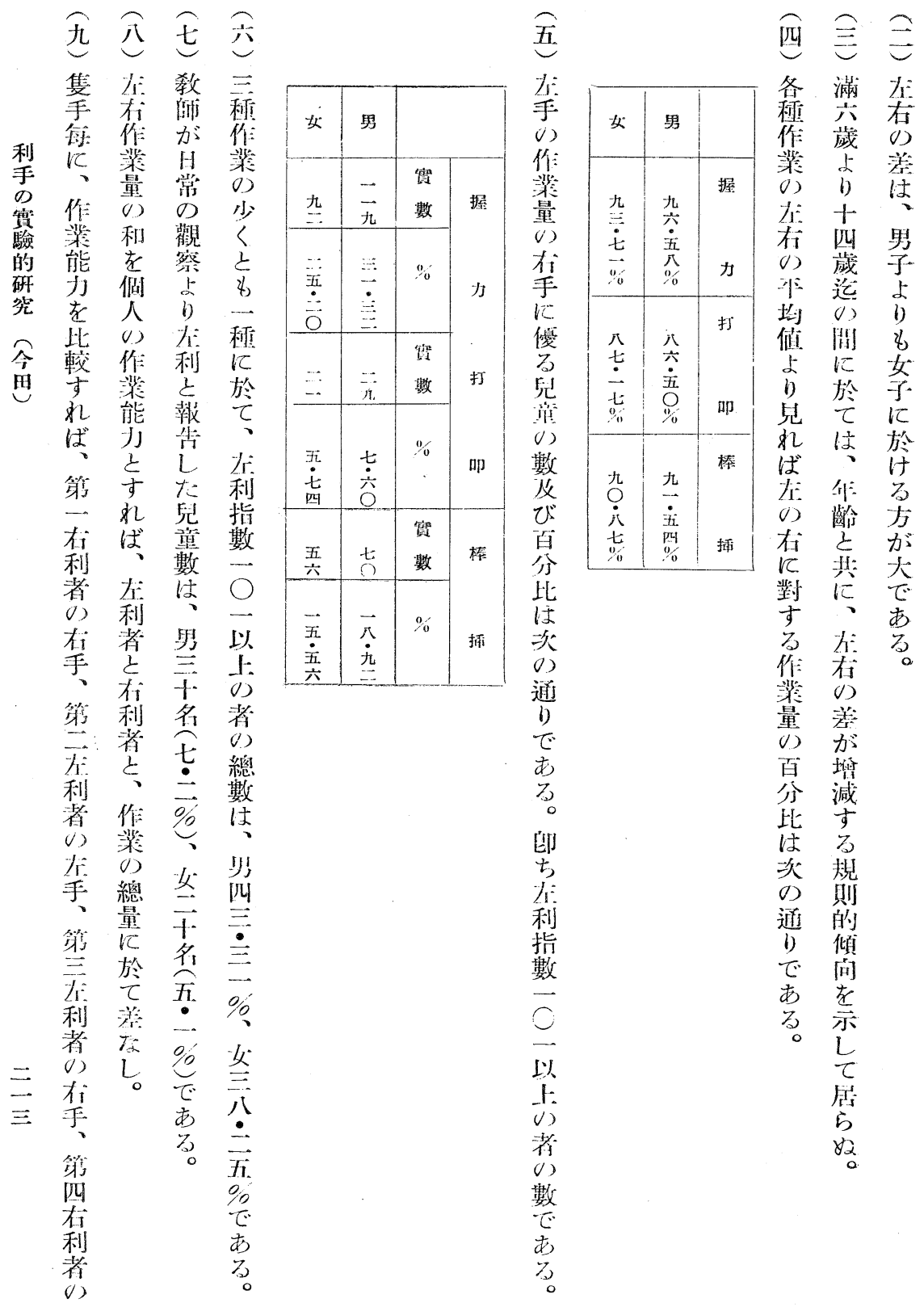




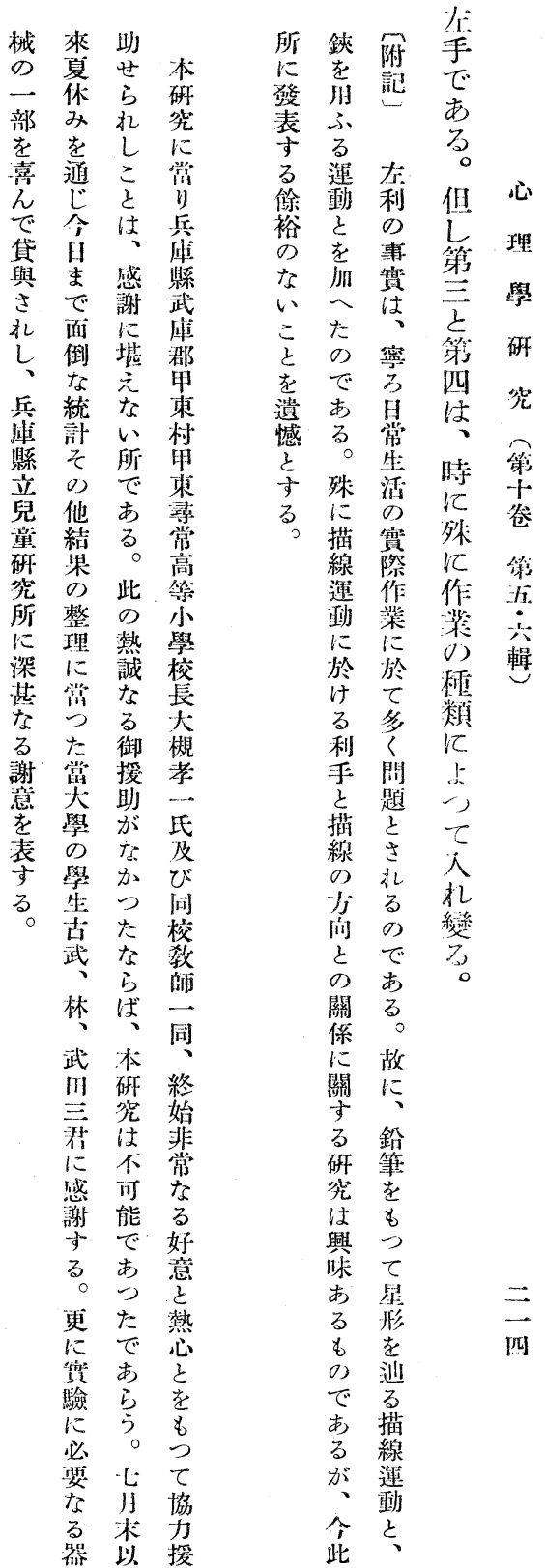


(From the Psychological Institute, Kwansei-Gakuin University)

\section{Experimental Study of Handedness}

\section{(Abstract)}

by

\section{Megumi Imada}

1. Problem of Hanciednes: Men are mostly right-handed, and left-handedness is exceptional, and as such it becomes a problem of interest and scientific research. But no definite theory of its origin and real nature has been established. The question of handedness has to be considered from two different angles. They are unilateral preference and unilateral superiority. Though they are inseparably united in the actual case, one refers to native tendency of using one hand in preference to the other, if it is native at all; and the other to the combined results of such tendency and post-natal practice.

This study aims to approach this question of handedness through the survey of the actual difference in the capacities of the two hands. And this question can be treated under three main headings.

(1) The actual facts of bilateral difference and the frefuency and degree of handedness.

(2) The causes of handednes.

(3) Physical and mental characteristicn of the left-handed.

2. Experiment: We chose tive different kinds of tests- (1) grip, (2) tapping for 30 second;, (3) pey-board for 1 minute, (4) tracing a star drawn with double lines (3 $\mathrm{mm}$ apart) with pencil, and (5) cutting with scissorsand administered to the entire group of children of one primary school, 801 in all, of whom 416 were boys and 391 were girls.

3. Results and Conclusions: This report includes only the first three tests mentioned above. The percentage of the capacities of the left hand to the right hand $(\mathrm{i}, \mathrm{s}, \mathrm{R} \times \mathrm{R} \times 100)$ was calculated and we called this an index of left-handediess.

(1) The average of motor capacities of each school year for boys and girls are given in Tables 1,2 and 3.

(2) According to the average of the capacities of both hands the relative 
efficiency of the left to the right is as follows.

$\begin{array}{cccc} & \text { Grip } & \text { Tapping } & \text { Peg Board } \\ \text { Boys } & 96.58 \% & 86.50 \% & 91.54 \% \\ \text { Girls } & 93.71 \% & 87.17 \% & 90.87 \%\end{array}$

(3) The percentage of children who show the left-hand superiority is as follows.

\begin{tabular}{|c|c|c|c|c|c|c|c|}
\hline Index of & & & ip & & ing & Peg & oard \\
\hline Left-handedness & & No. & $\%$ & No. & $\%$ & No. & 0 \\
\hline above 101 & Boys & 119 & 31.32 & 29 & 7.60 & 70 & 18.92 \\
\hline above 101 & Girls & 92 & 25.20 & 21 & 5.74 & 56 & 15.5 \\
\hline
\end{tabular}

(4) The number of individuals who show left-liand superiority in one, two, or three kinds of tests is 43.31 for boys and 38.25 for girls.

(5) The number of children reported as left-handed by teachers in charge is 30 (7.2\%) for boys and 20 (5.1\%) for girls.

(6) There is no difference of the total capacity of both hands betwcen the right-handed and the left-handed children.

(7) For one hand only the order of efficiency is as follows- 1st right hand of the right-handed, 2nd left hand of the left-handed, 3rd right hand of the left-handed, and 4 th left hand of the right-handed.

(8) The difference of the two hands is most marked in the speed of movement and not so marked in the strength.

(9) The difference of the two hands is greater with girls than with boys

(10) This research indicates that the frequency and degree of handedness do not regularly increase or decrease with the age-level. 